Supplement of Biogeosciences, 18, 4281-4303, 2021 https://doi.org/10.5194/bg-18-4281-2021-supplement (C) Author(s) 2021. CC BY 4.0 License.

(c) (i)

Supplement of

\title{
Do Loop Current eddies stimulate productivity in the Gulf of Mexico?
}

Pierre Damien et al.

Correspondence to: Pierre Damien (pdamien@ucla.edu)

The copyright of individual parts of the supplement might differ from the article licence. 
This supporting information provides one figure made from the model outputs. It is not essential for the understanding of the manuscript but provides substantial information.
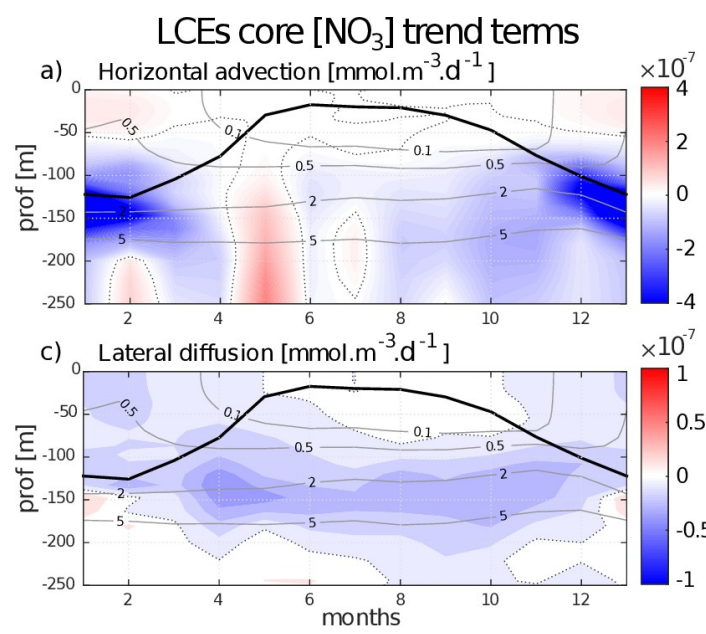

$$
\text { background } \mathrm{GoM}\left[\mathrm{NO}_{3}\right] \text { trend terms }
$$
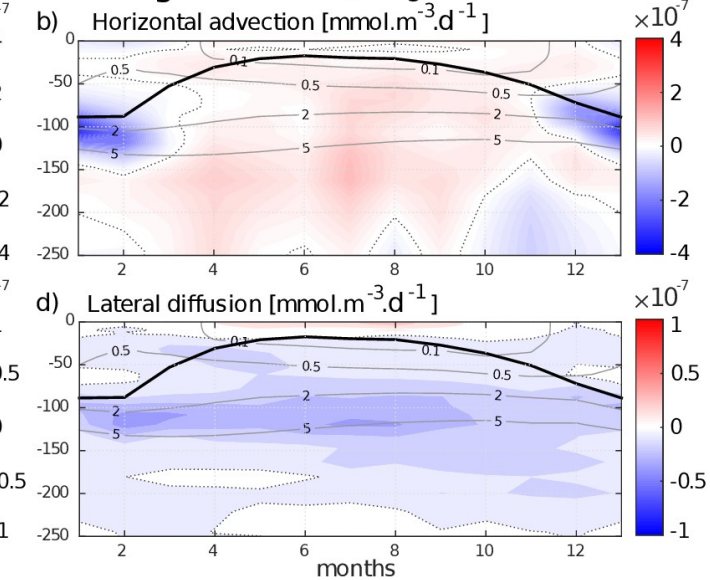

Figure S1: Seasonal cycle of nitrate trend terms in the (left column) LCEs core and in the (right column) background GoM. The trend induced by ( $a$ and $b$ ) horizontal advection and the (c and d) lateral mixing are represented. Isopycnals anomalies (gray contours) and the depth of the mixed layer (black line) are superimposed. 